\title{
NOTES ON THE DISTRIBUTION OF THE GARRY OAK IN BRITISH COLUMBIA
}

\author{
By R. G. Glendenning, Agazziz, B.C.
}

I Sudworth's "Forest Trees of the Pacific Slope," the general distribution of the Garry oak (2uercus garryana, Dougl) is given as:--"Valleys and dry gravelly slopes and table lands from Vancouver island southward through western Washington and Oregon into the coast ranges of northern and central California." The following additional note is also appended:"An isolated grove on the northwest end of Vancouver island on Quatsino sound, and another on the Fraser river $11 / 2$ miles above Yale. Described criginally from the plains around Vancouver on the mainland, but not seen there since."

Although these records of Sudworth's are generally mentioned in publications dealing with the forests or flora of British Columbia, they are usually doubted. This is not surprising, as the record at Quatsino is the only one on the west coast of Vancouver island, and is some 100 miles from the nearest main body of oaks on the south-east coast of the island; and the occurrence at Yale is the only record for the mainland of British Columbia. The remarks anent the plains around Vancouver refer to Vancouver, Washington, and not Vancouver, British Columbia; David Douglas having collected the type specimens near the former place circa 1824.

In order to clear up, if possible, the doubt surrounding this unusual distribution, the writer has recently investigated these records.

The occurrence at Yale was definitely located, the species there being confirmed as the true Garry oak. In addition, through the co-operation of Mr. J. W. Winson, of Huntingdon, an additional isolated occurrence was located on Sumas mountain, some ten miles west of Chilliwack.

The record at Quatsino I have been unable to verify by personal visit, but correspondence with the provincial forest ranger there, Mr. G. H. Waller, elicited the fact that at least one old timer in the district knew of oaks there, but logging operations had since obliterated the grove.

I, also have information that oaks occur at Stout, a station on the Canadian National railway, six miles east of the Yale occurrence, but have been unable to confirm this. If there, they are limited in number and distribution.

From an examination of the age and extent of the occurrences at Yale and Sumas it would appear that the oaks there are not relicts, but fairly recent extensions of the range of this species. The oldest tree at Yale is 
between eighty and ninety years old, and no dead stumps or dying trees have been found. Oaks of varying ages cover an area of about 50 acres, and seedlings are abundant where the soil is favourable. The occurrence at Sumas is younger and more limited in extent, some forty trees being found here, the oldest of which is approximately thirty-five years of age, but seedlings and suckers are plentiful as at Yale.

The mode of origin of these interesting records of discontinuous distribution is unknown, but from the age and location, which apparently rule against human agency, it would appear more likely that the wild pigeon had been the means of dispersal. The Yale grove is about 100 miles from the nearest stand of the oak at Fairhaven in Washington state; the Sumas grove being 35 miles from the same point. It is well known that the wild pigeon feeds voraciously on acorns, and with a crop full of these seeds would be very likely to fall prey to a falcon or other hawk, the contents of the crop thus being spilled by accident.

It would be most interesting to know from whom Sudworth received word of these interesting isolated records.

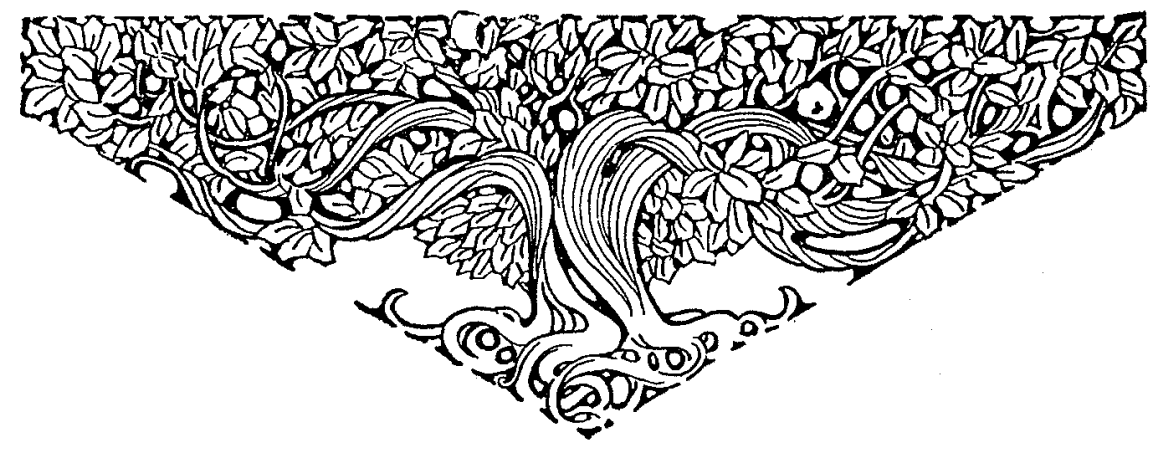

